Research Article

\title{
Investigation on Microstructure and Tensile Properties of High-Strength AA2014 Aluminium Alloy Welds Joined by Pulsed CMT Welding Process
}

\author{
Rajendran Chinnasamy ${ }^{D},{ }^{1}$ Samson Jerold Samuel Chelladurai ${ }^{(D},{ }^{1}$ and Tushar Sonar ${ }^{2}$ \\ ${ }^{1}$ Department of Mechanical Engineering, Sri Krishna College of Engineering and Technology, Coimbatore 641008, India \\ ${ }^{2}$ Centre for Materials Joining and Research (CEMAJOR), Department of Manufacturing Engineering, Annamalai University, \\ Annamalainagar 608002, India
}

Correspondence should be addressed to Samson Jerold Samuel Chelladurai; samsonjeroldsamuel@skcet.ac.in

Received 30 May 2021; Revised 16 August 2021; Accepted 2 September 2021; Published 23 October 2021

Academic Editor: Akbar Heidarzadeh

Copyright $(92021$ Rajendran Chinnasamy et al. This is an open access article distributed under the Creative Commons Attribution License, which permits unrestricted use, distribution, and reproduction in any medium, provided the original work is properly cited.

\begin{abstract}
High-strength AA 2014 aluminium alloys are broadly employed for many applications because of their good mechanical properties, high strength-to-weight ratio, and better resistance to corrosion and are recyclable. The major problems in welding of AA 2014 aluminum alloy using a traditional joining process are partially melted zone, hot cracking, and alloy segregation. Cold metal transfer-welding (CMT) process is an advanced variant of gas metal arc welding process characterized by reduced heat input in which the welding wire is retracted during the short circuit which allows sufficient time for the weld to cool before placing each drop. In this investigation, the pulsed CMT welding process was chosen to weld high-strength AA2014 aluminium alloy under T6 condition. The joint tensile properties were compared with the parent material and correlated to the microstructural features. The defect-free weld was achieved at constant welding speed of $450 \mathrm{~mm} / \mathrm{min}$, welding current of $110 \mathrm{~A}$, and electrode feed rate of $5550 \mathrm{~mm} / \mathrm{min}$. The joint weld using pulsed CMT yields a maximum strength of $303 \mathrm{MPa}$, extending joint efficiency up to $67 \%$. It mainly refers to the beneficial effects of welding wire pulsing and dip and retreat motion which causes refining of dendritic grains in weld metal and enhances the strength of joints.
\end{abstract}

\section{Introduction}

AA 2xxx alloy is precipitation hardening aluminium alloy preferentially employed in aerospace and automotive application owing to its good mechanical properties, resistance to general corrosion, high strength-to-weight ratio, and better formability. The light combat aircraft interstage skin and the automotive wheel are made from this alloy. The main problems encountered in welding high-strength agehardened Al-alloys, including AA2014, are cracking in weld metal and partially melted zone, porosity, and alloy segregation which constrain the fusion welding of AA2014 aluminium alloy (Babu et al, [1-9]). Hence, novel methods have been developed and commercialized over few decades. The TIG-welded aluminium alloy joints disclosed inferior strength properties which is almost half of the base material strength. It refers to high heat input requirement in TIG welding of aluminium alloy. This made researchers to practice low heat input solid state welding process popularly known as friction stir welding (FSW) process [10, 11] [12-16]. Several grades of aluminium alloys and dissimilar materials were fabricated using FSW. Moreover, the strength of friction stir welded joints is $75 \%-85 \%$ of the base material strength [17]. Even though, this process has limitations such as the exit hole at the end of the weld, CMT was invented in 2004 and is foreseen to be a breakthrough method in aluminium and its alloy welding. CMT is an advanced variant of GMAW in which the digital control detects the short circuit timing and detaches the drop by the retracting motion of welding wire during welding; the wire is moved forward and 
again pulled back as the short circuit happens. Thus, CMT arc introduces heat input only during the burning phase of arc. This lowers the heat input than traditional dip transfer welds [18]. Shang et al. investigated the mechanical and metallurgical characteristics of CMT-welded dissimilar materials. The intermetallic compounds have considerably affected strength. Pickin and Young [19] reviewed the role of CMT welding process in thick materials and pulsed GMAW. Finally, the CMT welding process was compared with pulsed GMAW. CMT welding process deposited a small amount of filler material in the weld by pulse frequency. Gungor et al. [20] used AA5083 and AA6082 for CMT welding. The materials were joined using two welding processes such as pulsed robotic CMT welding and MIG welding. The test results showed that the CMT welded joints had good tensile and fatigue strength. Azar [21] proposed a model to predict the heat input and geometry of CMT weld. This model explained the behavior of weld pool and formation of weld pool with respect to heat input. [22] and analyzed the formation of weld defects in CMT welded 5083 plates and joint performance. In the fusion zone, a dendritic structure with a significant percentage of big pores was found. Inadequate surface cleaning before welding was the cause of the creation of big pores. The failure mechanism was also influenced by the existence of large pores, which dictated the fracture growth path. The crack propagated within the fusion zone by jumping from one pore to the next, resulting in brittle failure.

The research work on CMT welding of aluminium alloy is mainly reported on $5 \mathrm{xxx}, 6 \mathrm{xxx}$, and $7 \mathrm{xxx}$ series grade. The information available on P-CMT welding of AA2014 aluminium alloy is scanty. It is necessary to investigate the strength properties and microstructural features of AA2014T6 aluminium alloy and compare the joint performance with base material for its viability in the concerned applications. Hence, an attempt has been made to weld AA2014-T6 aluminum alloy using pulsed CMT welding.

\section{Work Methodology}

Cold rolled sheets (AA2014-T6) with a thickness of $2 \mathrm{~mm}$ were used in this work. The chemical properties and mechanical properties of the base material (BM) were presented in Tables 1 and 2, respectively. The mechanical properties of $\mathrm{BM}$ were evaluated using a tensile test. The grain size of BM was $50 \mu \mathrm{m}$ (Figure 1(a)). A test coupon size of $150 \mathrm{~mm} \times 150 \mathrm{~mm}$ was prepared for the weld. CMT-2000x version machine (Figure 1(b)) was used to make a joint with a constant current of $110 \mathrm{~A}$, a voltage of $12 \mathrm{~V}$, welding speed of $45 \mathrm{~cm} / \mathrm{min}$, gas flow rate of $5 \mathrm{lpm}$, and wire travel speed of $555 \mathrm{~cm} / \mathrm{min}$ (Table 3). The photograph of P-CMT welded joint is shown in Figure 1(c). Composite tensile specimens were extracted from the weld in accordance with the ASTM E8-M04 guidelines (Figure 1(d)). The process parameters were illustrated in Figure 1(e). The machined samples were used for tensile test. Tensile test was conducted using $100 \mathrm{kN}$ electromechanically controlled UTM with a slide velocity of $0.15 \mathrm{~cm} / \mathrm{min}$. For metallography examination, a rectangular piece of the sample was cut from the middle portion of the weld line. Different grades of sand paper were used to polish the weld sample with alumina powder. The heat developed during welding was calculated using the following equation:

$$
\text { Heat generation } Q(\mathrm{~kJ} / \mathrm{mm})=\frac{\text { Welding current }(A) x \text { Thermal efficiency factor }(\eta) x \operatorname{Voltage}(V)}{1000 x \text { Welding speed }(\mathrm{mm} / \mathrm{min})} \text {. }
$$

To reveal the structure of weld and other regions, the polished sample was etched with Keller's reagent. The hardness distribution across the weld was performed using Vickers microhardness test and was carried out as per the ASTM- E384, and the applied load of $0.5 \mathrm{~N}$ and dwell time of $15 \mathrm{sec}$ were used. A scanning electron microscope was used to measure the type of failure pattern in the tensile tested sample. Moreover, EDS analysis was performed in the fractured region using energy dispersive spectroscopy.

\section{Results}

3.1. Tensile Test. The strength properties of AA 2014 P-CMT joints are presented in Table 4 . The strength properties were taken from an average of three samples in tensile test. From the results, the welded joint yields inferior strength than the parent material in as received conditions because of the differences in microstructural features, orientation of grains, and sizes in different regions. It affects the plastic deformation behavior during tensile load. However, the temperature rises above 200 degrees, and it causes the reversion of precipitate ( $\left.\theta^{\prime \prime}\right)$ at WZ and HAZ on cooling. This may be the reason for lower hardness and strength. P-CMT weld conceived a maximum tensile strength of $303 \mathrm{MPa}$, and it is $33 \%$ lower than the base material strength. The yield strength and percentage of elongation of CMT weld were $258 \mathrm{MPa}$ and $6.5 \%$, respectively (Figure 2). The reason for the material in as received condition possesses maximum strength is the presence of strengthening precipitates in its matrix and tempering condition. The P-CMT joint showed an efficiency of $67 \%$.

3.2. Hardness Survey. The hardness measurement across the transverse direction of weld is shown in Figure 3. The hardness distribution in the materials depends on two criteria such as size and distribution of precipitates and size of the grains. It is an inverse proportion to the grain size and precipitate size. The formation of recrystallized grains and distribution of strengthening precipitates in CMT weld is carried out by the heating and cooling process during thermal cycle. Hence, the hardness distribution has a direct relationship with weld strength. The weld region conceived a peak hardness of $88 \mathrm{HV}$ and $\mathrm{HAZ}$ was $72 \mathrm{HV}$. Moreover, the 
TABLE 1: Elemental composition (wt. \%.) of AA2014-T6 alloy (base material).

\begin{tabular}{lcccccccc}
\hline $\mathrm{Si}$ & $\mathrm{Cu}$ & $\mathrm{Fe}$ & $\mathrm{Mg}$ & $\mathrm{Cr}$ & $\mathrm{Zn}$ & $\mathrm{Mn}$ & $\mathrm{Ti}$ & \\
\hline 0.871 & 4.812 & 0.131 & 0.732 & 0.004 & 0.061 & 0.811 & 0.011 & $\mathrm{Bal}$ \\
\hline
\end{tabular}

TABle 2: Mechanical properties of nonwelded parent metal.

\begin{tabular}{lcccc}
\hline Material & $0.2 \%$ YS $(\mathrm{MPa})$ & UTS $(\mathrm{MPa})$ & $\%$ elongation $(50 \mathrm{~mm}$ gauge length) & Microhardness (HV) \\
\hline AA2014 & 430 & 454 & 8.5 & 162 \\
\hline
\end{tabular}

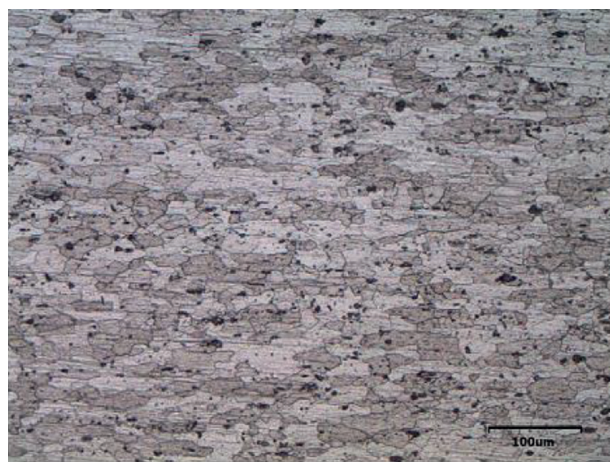

(a)

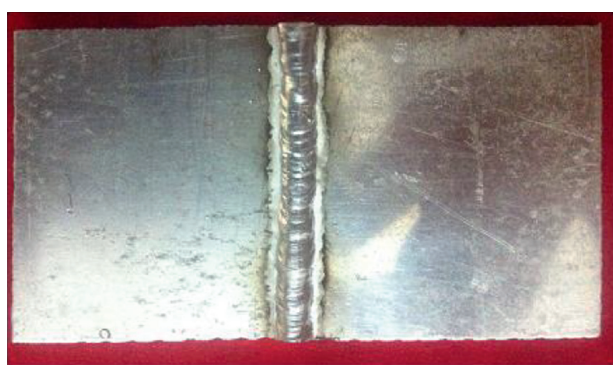

(c)

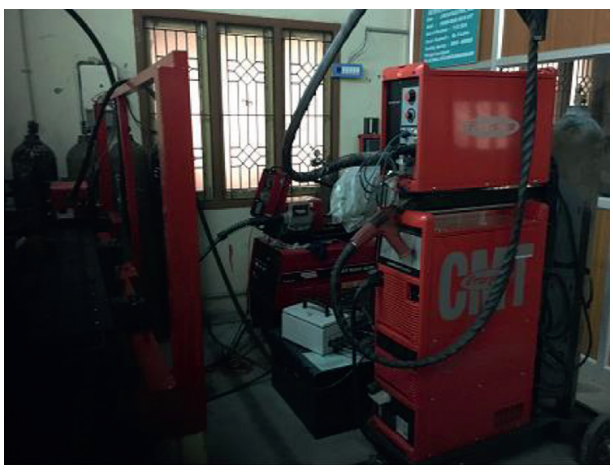

(b)

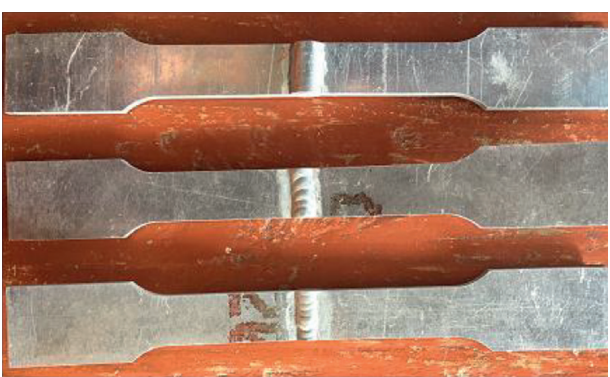

(d)

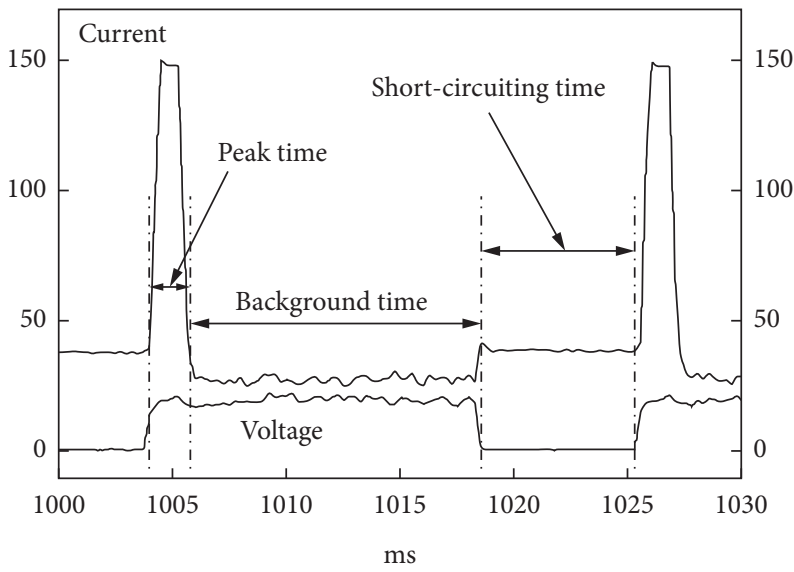

(e)

Figure 1: (a) Microstructure of base material. Photograph of (b) CMT machine, (c) fabricated P-CMT welded joint, (d) tensile specimens, and (e) process parameters [23].

$\mathrm{HAZ}$ is the weaker region irrespective of the welding process. Due to formation of the soft region [24], HAZ is adjacent to the fusion zone, where this zone experienced severe heat input followed by a slow cooling rate. As results, the grains were coarsened. The precipitate in HAZ may be coarsened or partially destructed. Moreover, the dispersion of strengthening precipitate was lower. Hence, the soft region was formed. This region will act as a crack initiation 
TABle 3: Optimized P-CMT welding parameters.

\begin{tabular}{|c|c|c|c|c|c|c|c|c|}
\hline \multirow[b]{2}{*}{$\begin{array}{l}\text { Joint } \\
\text { no. }\end{array}$} & \multirow[b]{2}{*}{$\begin{array}{l}\text { Arc voltage } \\
(\mathrm{V})\end{array}$} & \multicolumn{3}{|c|}{ P-CMT parameters } & \multirow[b]{2}{*}{$\begin{array}{c}\text { Arc } \\
\text { length }\end{array}$} & \multirow[b]{2}{*}{$\begin{array}{l}\text { Heat input } \\
(\mathrm{KJ} / \mathrm{mm})\end{array}$} & \multirow[b]{2}{*}{$\begin{array}{l}\text { UTS } \\
(\mathrm{MPa})\end{array}$} & \multirow[b]{2}{*}{ Probable reason } \\
\hline & & $\begin{array}{c}\text { Welding } \\
\text { current }(\mathrm{A})\end{array}$ & $\begin{array}{l}\text { Wire feed rate } \\
(\mathrm{mm} / \mathrm{min})\end{array}$ & $\begin{array}{l}\text { Welding speed } \\
(\mathrm{mm} / \mathrm{min})\end{array}$ & & & & \\
\hline 1 & 12 & 90 & 5500 & 450 & 15 & 0.121 & - & $\begin{array}{l}\text { Low heat input causes lack of } \\
\text { fusion }\end{array}$ \\
\hline 2 & 12 & 100 & 5500 & 450 & 15 & 0.188 & 255 & $\begin{array}{c}\text { Moderate heat causes coarse } \\
\text { grain }\end{array}$ \\
\hline 3 & 12 & 110 & 5500 & 450 & 15 & 0.223 & 303 & $\begin{array}{c}\text { Fine and recrystallized grains } \\
\text { by an optimum heat }\end{array}$ \\
\hline 4 & 12 & 120 & 5500 & 450 & 15 & 0.312 & 286 & $\begin{array}{c}\text { Coarse and long grains cause } \\
\text { by high heat input }\end{array}$ \\
\hline 5 & 12 & 130 & 5500 & 450 & 15 & 0.389 & - & $\begin{array}{l}\text { High heat input causes } \\
\text { porosity and coarse grains }\end{array}$ \\
\hline
\end{tabular}

TABLE 4: Tensile test results of PCMT welded aluminium alloy joint.

\begin{tabular}{|c|c|c|c|c|c|c|c|}
\hline \multirow[t]{2}{*}{ Joint No } & \multirow[t]{2}{*}{ Condition } & \multicolumn{2}{|c|}{$\begin{array}{l}\text { Microhardness } \\
(\mathrm{HV})\end{array}$} & \multirow{2}{*}{$\begin{array}{c}0.2 \% \mathrm{YS} \\
(\mathrm{MPa})\end{array}$} & \multirow[t]{2}{*}{$\%$ elongation (50 $\mathrm{mm}$ gauge length) } & \multirow[t]{2}{*}{ UTS (MPa) } & \multirow[t]{2}{*}{ Efficiency (\%) } \\
\hline & & WZ & HAZ & & & & \\
\hline 1 & P-CMT welded joint & 88 & 75 & 258 & 6.3 & 303 & $67 \%$ \\
\hline 2 & Base material & 155 & - & 431 & 9 & 455 & - \\
\hline
\end{tabular}

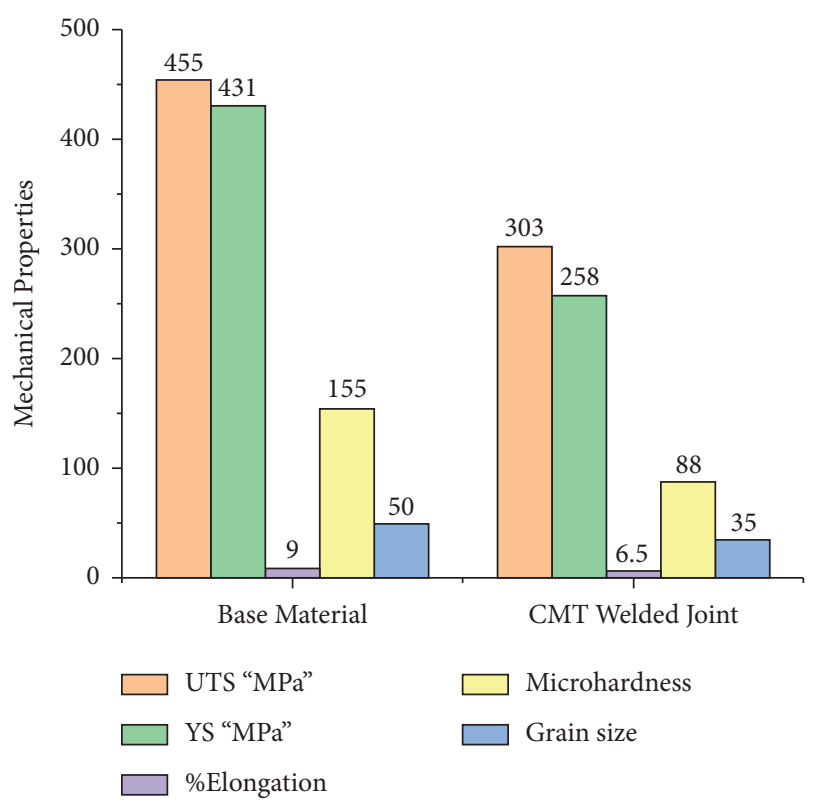

Figure 2: Tensile properties of P-CMT welded joint and base material.

point. Strengthening precipitate in as received condition is sensitive to the heat input during the welding cycle. It reduces the strength properties of joint, particularly, in the HAZ region. During artificial ageing of precipitation hardening aluminum alloy (AA2014-T6), the primary precipitates are needle-like $\left(\theta^{\prime \prime}\right)$, which is the main strengthening precipitate in $\alpha$-aluminium [25]. The spread of precipitate is uniform in the matrix. Due to thermal driving forces, the needle-like precipitate was transferred into a metastable $\left(\theta^{\prime}\right)$ precipitate whose presence along with

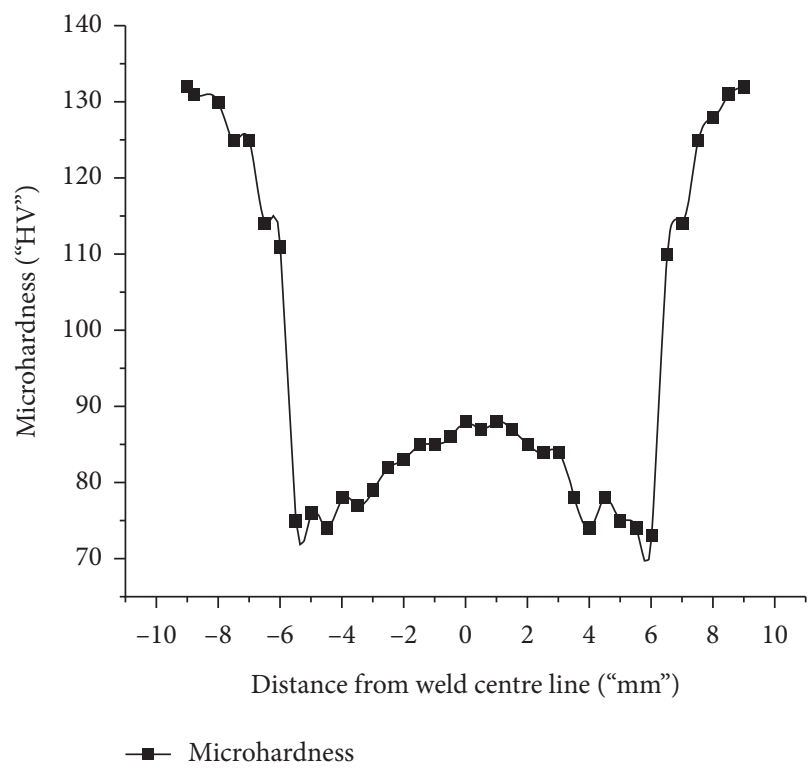

Figure 3: Microhardness profile.

aluminum becomes predominant in the WZ. This phenomenon is the main factor to reduce the hardness and strength. Moreover, the precipitate changes from $\theta^{\prime \prime}$ to $\theta$, causing a soft zone in the WZ [26].

3.3. Microstructure. The macrograph of P-CMT joint is revealed in Figure 4(a). No visible flaws were observed in the welded joints. The fusion zone of the weld showed brighter appearance than the other region due to recrystallization of grains and the geometry of the weld exhibits in elliptical shape. The mean value of grains in the weld (Figure 4(b)), 


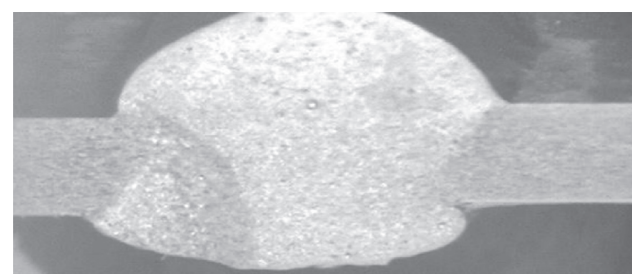

(a)

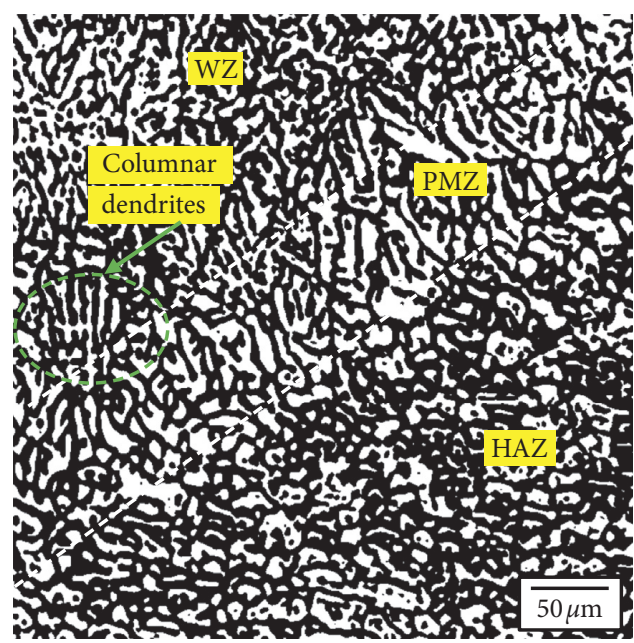

(c)

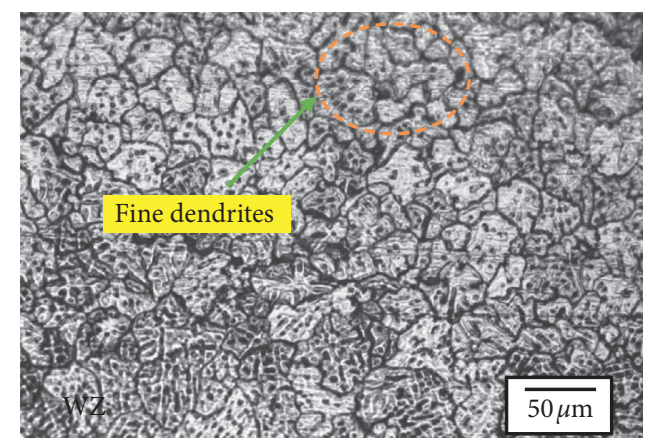

(b)

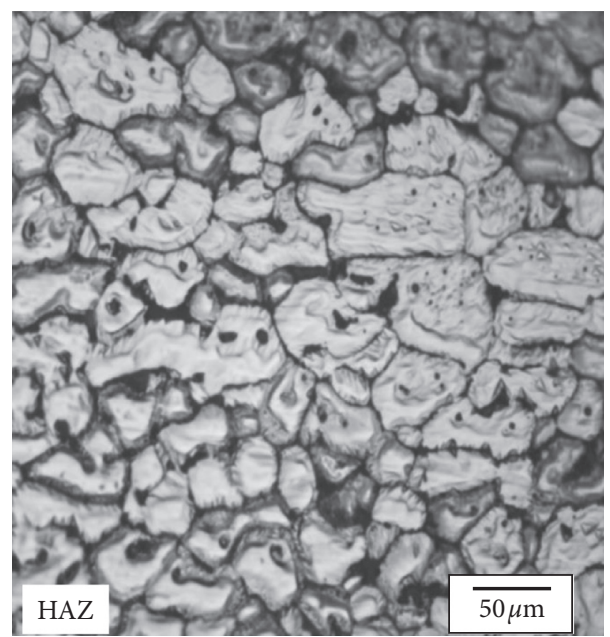

(d)

Figure 4: (a) Macrograph. Micrograph of (b) fusion zone, (c) FZ and PMZ interface, and (d) HAZ.

partially melted zone (Figure 4(c)), and heat affected (Figure $4(\mathrm{~d})$ ) zone was $35 \mu \mathrm{m}, 38 \mu \mathrm{m}$, and $45 \mu \mathrm{m}$, respectively. The fusion zone of P-CMT weld is framed with columnar grains with the dendritic structure. The grain morphology varies in the order of equiaxed dendrites and coarse dendrite. The equiaxed dendrites begin from the fusion line to the center of the weld and are perpendicular to the fusion line and parallel to the weld line. As the rate of solidification slows down, the amount of solute in the solution increases. Furthermore, the field of constitutional super cooling significantly expands. When the size of equiaxed dendrites and its respective volume present in liquid weld metal exceed a certain stage, columnar dendrites stop growing and turn into equiaxed dendrite.

3.4. Fractography. The SEM (JEOL India Pvt. Ltd. Type: 6610LV JSM Oh, Japan) analysis was conducted primarily to clarify the failure mode (i.e., both brittle or ductile). The fracture morphology of tested specimens is shown in Figure 5. The fractography does provide useful information about the role of microvoids on strength properties of joint. The fracture surface of high-strength aluminium alloy in as received condition showed fine and deep dimples (Figure 5(a)), whereas wider and shallow dimples were found in the joint welded with P-CMT. It suggests the larger fracture energy stored during tensile load. Although, the fracture was propagated along the grain boundary, it suggests the fracture mode was intergranular.

\section{Discussion}

The P-CMT welded AA2014-T6 joint revealed maximum tensile strength of $303 \mathrm{MPa}$ compared to $455 \mathrm{MPa}$ of parent metal. This extends joint efficient up to $67 \%$. By short circuiting and current pulsing, the highest weld strength is due to wire retraction, resulting in the development of refined dendritic grains in weld metal, enhancing the tensile properties of CMT joint in the pulsing mode. Coarse grain formation with partial destruction or size variation in harder precipitates in the HAZ area and is the cause for the breaking point in the HAZ zone [24]. As compared to arcing and short circuiting, the welded metal microstructure of P-CMT joints yields refined dendritic grains that are columnar in shape since the process is connected to a pulse stage with adequate heat input [19]. This pulsing effect, along with the faster cooling rate, helps the grains refine thoroughly. The microstructure of the welding metal is not as refined as it is for CMT joints [27]. The hardness properties in different regions of the joint were based on its microstructural behavior due to the unavailability of pulsation compared to the P-CMT joint [28]. Its high hardness was given by various 


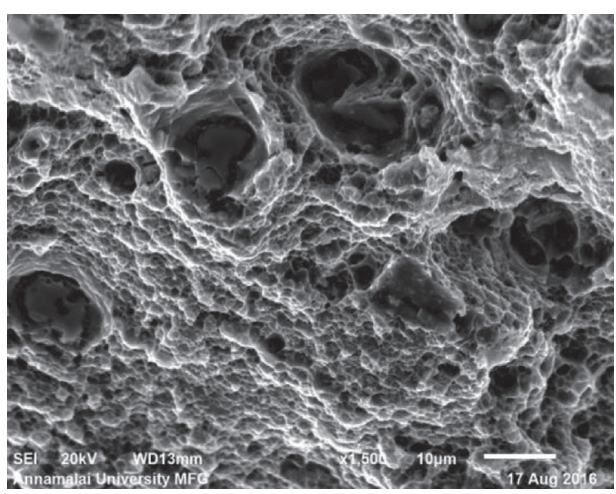

(a)

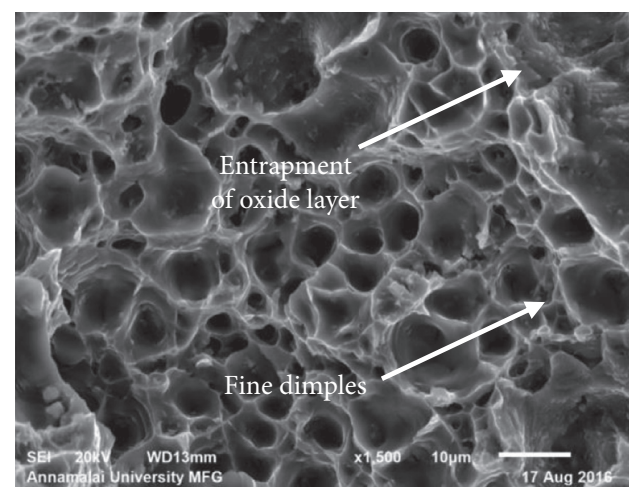

(b)

Figure 5: SEM fractography of (a) BM and (b) PCMT welded joint.

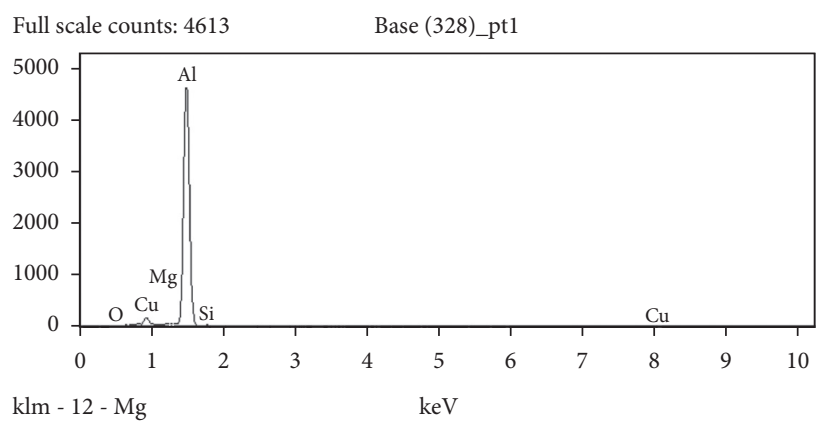

FIGURE 6: EDS analysis of the partially melted zone.

intermetallic compounds of $\mathrm{Mg}, \mathrm{Cu}$, and $\mathrm{Al}$ or by two of them produced near the fusion region $[29,30]$. The weld metal revealed somewhat higher hardness associated to the HAZ zone; although dissolution of precipitate in the weld zone was completely. The region adjacent to the fusion zone is a soft region. Due to the microsegregation of brittle eutectic $\left.(\alpha-\mathrm{Al})+\theta^{\prime \prime}\right)$, when the grain boundary is heated above the eutectic temperature, the liquation will partially form [31]. This eutectic microsegregation weakens the PMZ, and in the tensile strains, it can result in intergranular cracking. The PMZ is differentiated in the fusion welding process by the formation of equiaxed to columnar grains caused by high heat input. And, the volume of microsegregated eutectic rises as the peak temperature increases, while the concentration of solutionized $\mathrm{Cu}$ in the alpha aluminium decreases. In addition, the high concentration electromagnetic force produces a constitutional super-cooling effect to the P-CMT process in the fusion region, which helps regulate phase division tremendously. The hardness of the fusion zone was, therefore, superior to the other zones.

The mechanism behind the formation of weld in highstrength aluminum alloy is the enhancement of the solid solution with $\mathrm{Cu}$ and $\mathrm{Mn}$. In the softened area, the minimum hardness was by coarsening or complete destruction of harder phases (precipitates) [24, 32-34]. The greater electromagnetic force contributes the P-CMT process to a constitutional fastercooling impact that helps to regulate the division of stages immensely. In P-CMT, the pulsing effect is similar to the CMT process, which helps to dramatically monitor the degree of phase segregation and distribution in the weld region. By the low heat input $(0.164 \mathrm{KJ} / \mathrm{mm})$ during the welding cycle, brittle phase and variation in precipitate intensity were reduced considerably. With the formation of weld metal, a common soluble zone was created between the $\alpha$-aluminium and the welded metal. To disclose the cause behind the fracture point in the welded joint, EDS analysis was performed on the fractured sample. Most researchers claimed that HAZ was the fracture region of the fusion welding process. This area has since lost its precipitate reinforcement due to heat sensitivity during the welding cycle. EDS analysis (Figure 6) result showed that HAZ was composed of $\mathrm{Si}, \mathrm{Mg}, \mathrm{Si}, \mathrm{Cu}$, and $\mathrm{O}$ with aluminium. In addition, it consists of 94.97 percent (atom) of $\mathrm{Al}, 2.44$ percent of $\mathrm{Cu}, 0.75$ percent of $\mathrm{Mg}, 0.43$ percent of $\mathrm{Si}$, and 1.4 percent of $\mathrm{O}$, which showed that Al-based solid solution and $\mathrm{Al}_{2} \mathrm{CuMgSiO}_{2}$ eutectic structure were composed of this region.

\section{Conclusions}

The microstructural features and tensile properties of AA2014-T6 joints developed under optimized condition of $\mathrm{P}-\mathrm{CMT}$ welding were evaluated, and conclusions were made as follows:

(i) The AA2014-T6 aluminium alloy can be welded successfully using pulsed mode of cold metal transfer-welding (CMT) process without defects of cracking and porosity. 
(ii) The P-CMT AA2014 joints developed using a welding current of $110 \mathrm{~A}$, a welding speed of $450 \mathrm{~mm} / \mathrm{min}$, a voltage of $12 \mathrm{v}$, and a wire feed rate of $5500 \mathrm{~mm} / \mathrm{min}$ disclosed a maximum tensile strength of $303 \mathrm{MPa}$ compared to $455 \mathrm{MPa}$ of parent metal. This extends joints efficiency up to $67 \%$.

(iii) The enhancement in strength of P-CMT AA2014 joint is attributed to the combination of the wire's withdrawal motion and pulsing effect in the P-CMT process. The related pulsing mechanism, as well as the arcing and short-circuiting phases, help in refining the dendritic grains in weld metal which aids in controlling the eutectic phase segregation. This enhances the hardness of the weld metal region.

(iv) The failure occurred at the HAZ of P-CMT AA2014 joint due to the formation of lower eutectic elements in the HAZ and grain growth which lowers the hardness of HAZ compared to weld metal.

\section{Data Availability}

The data used to support the findings of this study are included within the article.

\section{Conflicts of Interest}

The authors declare that they have no conflicts of interest.

\section{References}

[1] G. Buffa, J. Hua, R. Shivapuri, and L. Fratni, "A continuum based fem model for friction stir welding-model development," Materials Science and Engineering A, vol. 419, no. 1-2, pp. 389-396, 2006.

[2] Z. W. Cen and S. Yazdanian, "Friction stir lap welding: material flow, joint structure and strength," Journal of Achievements in Materials and Manufacturing Engineering, vol. 55, pp. 629-637, 2012.

[3] H. Jamshidi, S. Serajzadeh, and A. Kokabi, "Theoretical and experimental investigation in to friction stir welding of AA5086," International Journal of Advanced Manufacturing Technology, vol. 52, no. 5, pp. 531-544, 2011.

[4] R. S. Mishra and Z. Y. Ma, "Friction stir welding and processing," Materials Science and Engineering: $A R$, vol. 50, no. 1-3, pp. 1-78, 2005.

[5] Y. Tian, J. Shen, S. Hu, Z. Wang, and J. Gou, "Effects of ultrasonic vibration in the CMT process on welded joints of $\mathrm{Al}$ alloy," Journal of Materials Processing Technology, vol. 259, pp. 282-291, 2018.

[6] E. Ünel and E. Taban, "Properties and optimization of dissimilar aluminum steel CMT welds," Welding in the World, vol. 61, no. 1, pp. 1-9, 2017.

[7] Y. Liang, S. Hu, J. Shen, H. Zhang, and P. Wang, "Geometrical and microstructural characteristics of the TIG-CMT hybrid welding in 6061 aluminum alloy cladding," Journal of Materials Processing Technology, vol. 239, pp. 18-30, 2017.

[8] Z. Xin, Z. Yang, Z. Han, and Y. Chen, "Comparative study on welding characteristics of laser-CMT and plasma-CMT hybrid welded AA6082-T6 aluminum alloy butt joints," Materials, vol. 12, Article ID 3300, 20 pages, 2019.

[9] Q. Sun, J. Li, Y. Liu, Y. Jiang, K. Kang, and J. Feng, "Arc characteristics and droplet transfer process in CMT welding with a magnetic field," Journal of Manufacturing Processes, vol. 32, pp. 48-56, 2018.

[10] Y. J. Kwon, I. Shigematsu, and N. Saito, "Dissimilar friction stir welding between magnesium and aluminium alloys," Materials Letters, vol. 62, pp. 3827-3829, 2008.

[11] J. C. Yan, Z. W. Xu, Z. Y. Li, L. Li, and S. Q. Yang, "Microstructure characteristics and performance of dissimilar welds between magnesium alloy and aluminium formed by friction stirring," Scripta Materialia, vol. 53, pp. 585-589, 2005.

[12] F.-y. Shu, T. Ze, L. ü. Yao-hui, and W.-x. He, L. ü. Fei-yang, J.-j. Lin, H.-y. Zhao, and B.-s. Xu, "Prediction of vulnerable zones based on residual stress and microstructure in CMT welded aluminum alloy joint," Transactions of Nonferrous Metals Society of China, vol. 25, no. 8, pp. 2701-2707, 2015.

[13] X. Fang, L. Zhang, H. Li, C. Li, K. Huang, and B. Lu, "Microstructure evolution and mechanical behavior of 2219 aluminum alloys additively fabricated by the cold metal transfer process," Materials, vol. 11, no. 5, p. 812, 2018.

[14] H. Liu, S. Yang, C. Xie, Q. Zhang, and Y. Cao, "Mechanisms of fatigue crack initiation and propagation in 6005A CMT welded joint," Journal of Alloys and Compounds, vol. 741, pp. 188-196, 2018.

[15] Z. Silvayeh, B. Götzinger, K. Werner, M. Hartmann, and C. Sommitsch, "Calculation of the intermetallic layer thickness in cold metal transfer welding of aluminum to steel," Materials, vol. 12, no. 1, p. 35, 2019.

[16] B. Cong, R. Ouyang, B. Qi, and J. Ding, "Influence of cold metal transfer process and its heat input on weld bead geometry and porosity of aluminum-copper alloy welds," Rare Metal Materials and Engineering, vol. 45, no. 3, pp. 606-611, 2016.

[17] C. Rajendran, K. Srinivasan, V. Balasubramanian, H. Balaji, and P. Selvaraj, "Evaluation of load-carrying capabilities of friction stir welded, TIG welded and riveted joints of AA2014T6 aluminium alloy," Aircraft Engineering \& Aerospace Technology, vol. 19, no. 9, 2019.

[18] R. R. Ambriz, G. Barrera, R. García, and V. H. López, "The microstructure and mechanical strength of Al-6061-T6 GMA welds obtained with the modified indirect electric arc joint," Materials \& Design, vol. 31, no. 6, pp. 2978-2986, 2010.

[19] C. G. Pickin and K. Young, "Evaluation of cold metal transfer (CMT) process for welding aluminium alloy," Science and Technology of Welding \& Joining, vol. 11, no. 5, pp. 583-585, 2006.

[20] B. Gungor, E. Kaluc, E. Taban, and A. Sik Ș, "Mechanical and microstructural properties of robotic cold metal transfer (CMT) welded 5083-H111 and 6082-T651 aluminum alloys," Materials \& Design, vol. 54, pp. 207-211, 2014.

[21] A. S. Azar, "A heat source model for cold metal transfer (CMT) welding," Journal of Thermal Analysis and Calorimetry, vol. 122, no. 2, pp. 741-746, 2015.

[22] L. Yin, J. Wang, H. Hu, S. Han, and Y. Zhang, "Prediction of weld formation in 5083 aluminum alloy by twin-wire CMT welding based on deep learning," Welding in the World, vol. 63, no. 4, pp. 947-955, 2019.

[23] S. Selvi, A. Vishvaksenan, and E. Rajasekar, "Cold metal transfer (CMT) technology-An overview," Defence technology, vol. 14, no. 1, pp. 28-44, 2018.

[24] R. R. Ambriz, D. Chicot, and N. Benseddiq, "Local mechanical properties of the 6061-T6 aluminium weld using microtraction and instrumented indentation," European Journal of Mechanics-A/Solids, vol. 30, pp. 307-315, 2011. 
[25] S. Babu, G. D. Janaki ram, and P. V. Venkatakrishnan, G. Madusudhana Reddy, K. Prasad Rao, "Microstructure and mechanical properties of friction stir lap welded aluminium alloy AA2014," Journal of Materials Science \& Technology, vol. 28, no. 5, pp. 414-426, 2012.

[26] A. Ramaswamy, S. Malarvizhi, and V. Balasubramanian, "Effect of variants of gas metal arc welding process on tensile properties of AA6061-T6 aluminium alloy joints," International Journal of Advanced Manufacturing Technology, vol. 108, no. 9, pp. 2967-2983, 2020.

[27] B. Gungor, E. Kaluc, E. Taban, and S. I. K. Aydin, "Mechanical and microstructural properties of robotic Cold Metal Transfer (CMT) welded 5083-H111 and 6082-T651 aluminum alloys," Materials \& Design, vol. 54, pp. 207-211, 2014.

[28] J. Shang, K. Wang, Q. Zhou, D. Zhang, J. Huang, and G. Li, "Microstructure characteristics and mechanical properties of cold metal transfer welding $\mathrm{Mg} / \mathrm{Al}$ dissimilar metals," $M a$ terials \& Design, vol. 34, pp. 559-565, 2012.

[29] R. R. Ambriz, G. Barrera, R. García, and V. H. López, "Effect of the weld thermal cycles of the modified indirect electric arc on the mechanical properties of the AA6061-T6 alloy," Welding International, vol. 24, no. 4, pp. 321-328, 2010.

[30] L. M. Liu, X. J. Liu, and S. H. Liu, "Microstructure of laser-TIG hybrid welds of dissimilar $\mathrm{Mg}$ alloy and $\mathrm{Al}$ alloy with $\mathrm{Ce}$ as interlayer," Scripta Materialia, vol. 55, pp. 383-386, 2006.

[31] S. Y. Chang, L. C. Tsao, T. Y. Li, and T. H. Chuang, "Joining 6061 aluminum alloy with Al-Si-Cu filler metals," Journal of Alloys and Compounds, vol. 488, pp. 174-180, 2009.

[32] C. Rajendran, K. Srinivasan, V. Balasubramanian, H. Balaji, and P. Selvaraj, "Effect of post weld heat treatment on strength and microstructure of friction stir welded lap joints of AA2014-T6 aluminum alloy," Metal Science and Heat Treatment, vol. 61, no. 5, pp. 305-310, 2019.

[33] C. Rajendran, K. Srinivasan, V. Balasubramanian, H. Balaji, and P. Selvaraj, "Effect of tool tilt angle on strength and microstructural characteristics of friction stir welded lap joints of AA2014-T6 aluminum alloy," Transactions of Nonferrous Metals Society of China, vol. 29, no. 9, pp. 1824-1835, 2019.

[34] M. L. Zhu and F. Z. Xuan, "Correlation between microstructure, hardness and strength in HAZ of dissimilar welds of rotor steels," Materials Science and Engineering, vol. A527, pp. 4035-4042, 2010. 